Pawet Banaś

\title{
Naturalizm w prawie
}

\section{Wprowadzenie}

Celem opracowania jest omówienie konsekwencji przyjęcia stanowiska naturalizmu na gruncie teorii prawa, w szczególności w kontekście zagadnienia integracji zewnętrznej prawoznawstwa. We współczesnej filozofii naturalizm wydaje się stanowiskiem silnie zakorzenionym. Szczególnie na gruncie filozofii anglosaskiej określenie „naturalistyczny” zyskuje (być może już zyskało) charakter pozytywnie wartościujący. Również w polskiej teorii prawa zagadnienie naturalizmu było już wielokrotnie dyskutowane, przede wszystkim w kontekście sporu: naturalizm antynaturalizm $^{1}$ oraz integracji zewnętrznej nauk prawnych ${ }^{2}$. Wydaje się jednak, iż w polskiej literaturze z obszaru teorii prawa dominuje obraz naturalizmu, w którym jego ontologiczno-metodologiczne założenia przenikają się z przypisywaną mu pewną filozoficzną (czy raczej afilozoficzną) postawą (która też na ogół w tym opisie dominuje). W ramach niniejszego tekstu chciałbym odnieść się krytycznie do tego obrazu, wskazując na konsekwencje przyjęcia stanowiska naturalizmu na gruncie teorii prawa (w szczególności w kontekście programu integracji zewnętrznej nauk prawnych), które wynikają z jego ontologicznych i metodologicznych założeń.

Opracowanie składa się z dwóch części. Najpierw zarysuję obraz naturalizmu obecny w polskiej teorii prawa, podkreślając pewne jego dyskusyjne aspekty. Następnie przedstawię stanowisko naturalizmu, wskażę przykłady nurtów obecnych (historycznie lub współcześnie) w teorii prawa, którym naturalizm był bliski oraz, ostatecznie, zasugeruję konsekwencje przyjęcia stanowiska naturalizmu w kontekście zagadnienia integracji zewnętrznej nauk prawnych.

1 Np. L. Morawski, Główne problemy współczesnej filozofii prawa. Prawo w toku przemian, Warszawa 2005; J. Stelmach, Naturalistyczny i antynaturalistyczny model teorii prawa, „Studia Prawnicze" 1984, z. 3-4.

2 Np. J. Łakomy, Spór naturalizm versus antynaturalizm w naukach prawnych a zagadnienie integracji zewnętrznej nauk prawnych, [w:] M. Sadowski, P. Szymaniec (red.), Wrocławskie studia erazmiańskie. Prace z zakresu myśli polityczno-prawnej oraz elektronicznej administracji, Wrocław 2010. 


\section{Naturalizm w polskiej teorii prawa}

W literaturze można niekiedy spotkać pogląd $\mathrm{d}^{3}$, iż naturalizm był obecny (i dominował) w polskiej powojennej teorii prawa - w głównej mierze ze względu na uwarunkowania polityczne czasów komunizmu. Nie chcę w tym tekście przesądzać, na ile ów pogląd jest historycznie trafny. Bez wątpienia marksistowska postać naturalizmu jest dosyć specyficzna i powinno się zachować ostrożność przy dokonywaniu na jej podstawie jakichkolwiek generalizacji ${ }^{4}$. Niemniej, przytaczany pogląd sugeruje, iż ów skrzywiony obraz naturalizmu (w którym założenia ontologiczno-metodologiczne mieszały się z określoną postawą wobec prawa, filozofii i nauki w ogóle) do pewnego stopnia przeniknął do ówczesnej teorii prawa, uprawianej w duchu pozytywizmu prawniczego i filozofii analitycznej, prowokując, po upadku komunizmu, spór na linii: naturalizm - antynaturalizm.

Istotą tego sporu w naukach prawnych, analogicznego do podobnych sporów toczonych na gruncie chyba wszystkich nauk społecznych, jest poszukiwanie odpowiedzi na pytanie: czy i w jakim stopniu metody empiryczne i nieempiryczne są przydatne i stosowalne w ramach teorii prawa?

W tej dyskusji zwraca się uwagę, że dla nurtów „naturalistycznych” (takich jak pozytywizm prawniczy czy filozofia analityczna według cytowanego wyżej poglądu) wspólne jest wielopłaszczyznowe podejście do prawa, w którym postrzega się je równolegle z perspektyw, m.in. logiczno-językowej, psychologicznej i socjologicznej ${ }^{6}$. To wielopłaszczyznowe ujęcie ma charakter zarówno ontologiczny, jak i metodologiczny. Po pierwsze, prawo postrzegane jest jako ontologicznie złożone: $\mathrm{z}$ jednej strony mające postać językową, z drugiej - będące pewnym przeżyciem określonego podmiotu, ale też określonym faktem społecznym. Z kolei metodologiczny charakter zawiera postulat głoszący, że prawo może być badane metodami i narzędziami: logiki, nauki o języku, psychologii i socjologii. Uważa się również, że wielopłaszczyznowość metodologiczna prawoznawstwa pozostaje w obrębie paradygmatu naturalistycznego niejako ze swej istoty ${ }^{7}$. Oznacza to, że naturalizm, w którym prawo ujmowane jest na gruncie paradygmatu naturalistycznego jako pewien obiektywnie istniejący, empiryczny

3 Zob. J. Łakomy, Pojęcie integracji zewnętrznej nauk prawnych, [w:] M. Sadowski, P. Szymaniec (red.), Wrocławskie studia erazmiańskie. Zeszyty studenckie. Prace prawnicze, administratywistyczne i historyczne, Wrocław 2009; idem, Spór naturalizm versus antynaturalizm...

4 Marksizm z jednej strony w pewnym sensie postulował, że istnieje to, co dostępne empirycznie, a $\mathrm{z}$ drugiej - z góry narzucał nauce pewne ograniczenia.

5 J. Stelmach, op. cit.

6 Za: K. Opałek, J. Wróblewski, Prawo. Metodologia, filozofia, teoria prawa, Warszawa 1991. Postulowana często płaszczyzna aksjologiczna utożsamiana jest raczej z „podejściem antynaturalistycznym".

7 Zob. np. P. Jabłoński, O postawie filozoficznej w polskiej ogólnej refleksji nad prawem, [w:] O. Bogucki, S. Czepita (red.), System prawny a porzadek prawny, Szczecin 2008. Również: J. Łakomy, Spór naturalizm versus antynaturalizm... 
fakt $^{8}$, o wielowymiarowym, złożonym ontologicznie charakterze ${ }^{9}$, otwiera nauki prawne na narzędzia i metody stosowane w obrębie innych dyscyplin naukowych - a zatem działa w pewnym sensie „rozszerzająco”.

W konsekwencji wskazuje się, że naturalizm w teorii prawa wiąże się bezpośrednio $\mathrm{z}$ programem integracji zewnętrznej nauk prawnych, rozumianym (za K. Opałkiem) jako procesy ujednolicania badań prowadzonych przez nauki prawne i inne nauki, procesy koordynacji badań zachodzące między prawoznawstwem a innymi naukami oraz współpracę nauk prawnych z innymi ${ }^{10}$. Jakub Łakomy ${ }^{11}$ zauważa, że naturalizm sprzyja właśnie postawom integratywnym w teorii prawa, dla których przeciwieństwem są modele autonomiczne (bliższe ujęciu antynaturalistycznemu, w którym prawo może być ujmowane np. jako aksjologicznie autonomiczne, będące wartością samą w sobie, posługujące się własnymi metodami poznania). Co więcej, ten sam autor stawia tezę, iż przedsięwzięcia integracji zewnętrznej nauk prawnych z innymi naukami są w pełni zgodne i są wręcz naturalną konsekwencją przyjęcia postawy naturalizmu metodologicznego i przedmiotowe$\mathrm{go}^{12} \mathrm{~W}$ ogólnej refleksji nad prawem. W tym kontekście prawoznawstwo na gruncie naturalizmu jawi się jako nauka empiryczna ${ }^{13}$, w której zachowany jest swoisty przedmiot, rozszerzeniu ulega natomiast paleta dostępnych metod jego poznania.

Najbardziej charakterystyczne dla sporów wokół naturalizmu w polskiej teorii prawa jest ujmowanie go raczej jako pewnego ,paradygmatu naturalistycznego", który, jakkolwiek powołuje się na ontologiczne i metodologiczne założenia naturalizmu, to traktuje go raczej jako określoną postawę, sposób refleksji nad prawem oraz stosunek do niego i nauk empirycznych. Taki sposób ujmowania naturalizmu powoduje, że relacjonowanie sporu: naturalizm - antynaturalizm przejawia zwykle tendencję do rozważań bardziej socjologicznych niż metateoretycznych czy ściśle metodologicznych.

Przykładem takiego ujęcia jest teza P. Jabłońskiego ${ }^{14}$, który argumentuje, iż naturalizm sprzyja postawie afilozoficznej na gruncie teorii prawa, rozumianej jako niepowoływanie się na twierdzenia filozoficzne, pewien ,filozoficzny minimalizm", charakterystyczny dla pozytywizmu prawniczego czy filozofii analitycznej. Podobny charakter ma sugestia J. Łakomego, że „paradygmat naturalistyczny" sprzyja modelom integratywnym, projektom interdyscyplinarnym ${ }^{15}$.

8 J. Stelmach, op. cit.

9 K. Opałek, J. Wróblewski, Zagadnienia teorii prawa, Warszawa 1969.

${ }^{10}$ Zob. m.in. K. Opałek, Problemy ,wewnętrznej” $i$,,zewnętrznej” integracji nauk prawnych, „Krakowskie Studia Prawnicze” 1968, z. 1-2; idem, Swoistość prawoznawstwa a problem integracji, „Państwo i Prawo” 1966, nr 4-5.

11 J. Łakomy, Pojęcie integracji zewnętrznej...

${ }^{12}$ Zob. dalej wyjaśnienie tego rozróżnienia.

${ }_{13}$ J. Stelmach, op. cit.

${ }_{14}$ P. Jabłoński, op. cit.

15 J. Łakomy, Pojęcie integracji zewnętrznej... 
Oczywiście, tak przedstawiony obraz sposobu, w jaki zwolennik naturalizmu bywa postrzegany w polskiej teorii prawa, ma charakter wybiórczy i nie rości sobie prawa do bycia pełnym i wyczerpującym. Chodziło w nim przede wszystkim o zaakcentowanie pewnych dyskusyjnych (jak postaram się wykazać w dalszej części opracowania) jego aspektów oraz pokazanie, w jaki sposób uzasadnia się związek pomiędzy naturalizmem a programem integracji zewnętrznej nauk prawnych. Naturalizm w postaci, jaka jest niemal powszechnie akceptowana w filozofii anglosaskiej (niezależnie od szczegółowych sporów wewnętrznych), nigdy nie cieszył się porównywalną popularnością - czy to w wśród polskich filozofów, czy teoretyków prawa. Zapewne nie miał zatem możliwości objawić się we wszystkich swoich postaciach. Niemniej jednak pewne tezy, które pojawiają się w prezentacji poglądów naturalistycznych, wydają się pozbawione oparcia w jego ontologiczno-metodologicznych założeniach. Do takich tez można zaliczyć m.in. to, że:

- z naturalizmem bezpośrednio wiąże się wielopłaszczyznowe spojrzenie na prawo;

- antynaturalizm, w odróżnieniu od naturalizmu, sprzyja programom autonomicznym;

- naturalizm sprzyja postawie afilozoficznej.

W dalszej części tekstu postaram się wykazać kontrowersyjność powyższych tez.

\section{Naturalizm ontologiczny i metodologiczny}

Naturalizm jako stanowisko metafizyczne, wbrew temu, co sugeruje m.in. J. Stelmach ${ }^{16}$, nie jest stanowiskiem jednolitym. Wprost przeciwnie - liczba jego ujęć na gruncie współczesnej filozofii jest tak duża, iż sformułowanie wyczerpującej i niespornej definicji wydaje się niemożliwe ${ }^{17}$. Przede wszystkim trzeba odróżnić naturalizm ontologiczny od metodologicznego. Naturalizm ontologiczny (albo substancjalny, w skrócie: s-naturalizm) postuluje przede wszystkim, że istnieją tylko te byty, które są nam dostępne empirycznie (przyroda „wyczerpuje” rzeczywistość). Naturalizm metodologiczny (m-naturalizm) z kolei nie stawia mocnych tez ontologicznych, postuluje raczej, iż nauka i filozofia posługują się tymi samymi metodami, mają te same cele, ale odpowiadają na różne pytania. Rozróżnienie to, choć bardzo doniosłe, nie zawsze funkcjonuje $\mathrm{w}$ obrazie naturalizmu przyjmowanego na gruncie teorii prawa ${ }^{18}$. S-naturalizm

${ }^{16}$ J. Stelmach, op. cit.

${ }^{17}$ D. Papineau, Naturalism, [w:] E. N. Zalta (ed.), The Stanford Encyclopedia of Philosophy, Spring 2009 Edition; http://plato.stanford.edu/archives/spr2009/entries/naturalism (dostęp: 23.04.2014).

${ }^{18}$ Wyjątkiem jest L. Morawski, który za A. Pałubicką akcentował podział na naturalizm metodologiczny i przedmiotowy, który odpowiada mniej więcej prezentowanemu tu podziałowi na m-naturalizm i s-naturalizm. 
jest stanowiskiem silniejszym - raczej niemożliwe jest, by s-naturalista odrzucał m-naturalizm. M-naturaliści z kolei nie muszą być naturalistami ontologicznymi. Można postulować istnienie bytów niedostępnych empirycznie (jak Bóg, wolna wola czy świadomość), ale przyjmować, że nauka jest jedynym dostępnym nam sposobem poznania obiektywnej rzeczywistości. M-naturalista nie mówi, że bytów „supernaturalnych" nie ma, a jedynie to, że empiryczne poznanie naukowe jest najlepszym (lub nawet jedynym) źródłem obiektywnych informacji na temat tego, co jest (a byty ,supernaturalne" takiemu poznaniu mogą się wymykać).

Charakterystyczne dla naturalizmu, zarówno ontologicznego, jak i metodologicznego, jest to, iż jego celem jest raczej zawężanie niż rozszerzanie zbioru postulowanych bytów i metod poznania. S-naturalizm postuluje, że istnieje mniej bytów, niż zakładają to stanowiska antynaturalistyczne - nie istnieją te ,supernaturalne”. M-naturalizm z kolei odrzuca metody nieempiryczne jako narzędzia poznania ${ }^{19}$.

\subsection{S-naturalizm}

Postulowanie naturalizmu substancjalnego stanowi mocną tezę ontologiczną. Stanowisko takie jest jednak bardzo szerokie i dopuszcza w swoich ramach liczne dalsze spory i stanowiska bardziej szczegółowe. Naturalista np. może (choć nie musi) być redukcjonistą, eliminatywistą czy nominalistą.

Redukcjonizm jako stanowisko ontologiczne głosi, że istnieją tylko byty „podstawowe”, a byty złożone to co najwyżej ich zbiory. Mówiąc precyzyjniej: własności bytów złożonych mogą być zredukowane do własności bytów prostych w ten sposób, iż w bycie złożonym nie pojawi się nic jakościowo innego od tego, co występuje w sumie bytów prostych. W rezultacie byty złożone nie istnieją istnieje tylko to, do czego mogą zostać zredukowane ${ }^{20}$.

Eliminatywizm ${ }^{21}$ głosi, że jeśli postulowanie jakiegoś bytu nie jest nam niezbędne do wyjaśnienia rzeczywistości, to ten byt nie istnieje ${ }^{22}$. Na gruncie filozofii umysłu stanowisko to przyjmuje postać materializmu eliminatywnego, głoszącego, że jeśli pojęcia psychologii potocznej (takie jak uczucia, intuicje itd.) nie są nam potrzebne do wyjaśnienia zachowania - oznacza to, że po prostu nic nie oznaczają (co najwyżej pewne złudzenia). Tak ujmowany eliminatywizm stanowi radykalną aplikację argumentu z „brzytwy Ockhama”, postulującego oszczędność ontotologiczną.

19 D. Papineau, op. cit.

20 T. Nagel, Reductionism and antireductionism, [w:] G. R. Bock, J. A. Goode (red.), The Limits of Reductionism in Biology, Chichester 1998.

${ }^{21}$ Chodzi o wersję eliminatywizmu zasadzającą się na przedstawionej przez Rorty'ego pewnej teorii identyczności - disappereance theory.

${ }^{22}$ R. Rorty, Mind-body identity, privacy, and categories, ,Review of Metaphysics” 1965, no. 19. 
Nominalizm (w odróżnieniu od realizmu) głosi, iż nie istnieją tzw. uniwersalia; w filozofii anglosaskiej zwykle jednak stanowisko nominalizmu utożsamiane jest z odrzuceniem istnienia bytów abstrakcyjnych (czyli nie-czasoprzestrzennych) ${ }^{23}$.

Na tym tle widać wyraźnie, że obraz naturalisty, który dominuje we współczesnej teorii prawa, to obraz kogoś, kto rzeczywiście akceptuje istnienie tylko tych bytów, które są poznawalne empirycznie - uznając za taki byt prawo, które jest ontologicznie złożone i abstrakcyjne. Obraz naturalisty, któremu przeciwstawia się antynaturalistę, to obraz naturalisty antyredukcjonisty, który jest jednocześnie realistą prawnym.

Takie zestawienie stanowisk metafizycznych, raczej niezbyt powszechne wśród współczesnych filozofów ${ }^{24}$, jest jak najbardziej możliwe do przyjęcia. Trzeba jednak podkreślić, że nie jest uprawnione opisywanie naturalizmu wyłącznie przez pryzmat jego antyredukcjonistycznego i realistycznego ujęcia. Chcąc wskazać konsekwencje przyjęcia naturalizmu dla programu integracji zewnętrznej nauk prawnych, trzeba mieć świadomość różnic np. pomiędzy redukcjonistycznym i antyredukcjonistycznym obrazem świata ${ }^{25}$ - świat tego ostatniego zamieszkuje w końcu nieporównanie więcej bytów.

\subsection{M-naturalizm}

Naturalizm ontologiczny jest mocnym stanowiskiem metafizycznym. Znacznie słabsze zobowiązania wiążą się z m-naturalizmem. Naturalista metodologiczny nie interesuje się pytaniami o charakterze stricte ontologicznym. Zamiast tego wychodzi z założenia, iż ważniejsze jest pytanie o to, co można poznać. Według m-naturalisty poznać można mianowicie to, co jest dostępne za pośrednictwem metod empirycznych.

M-naturalistę w mniejszym stopniu interesuje pytanie o to, czym prawo jest - postuluje on raczej, że czymkolwiek by nie było, chcąc się czegoś o nim dowiedzieć, trzeba stosować metody empiryczne. Pojawiają się w tym miejscu wątpliwości, na ile jest to możliwe w sytuacji, gdy rezygnuje się z pewnych zobowiązań ontologicznych. Próbą wyjścia może być np. operacjonalizacja ${ }^{26}$ danego pojęcia na potrzeby badania, czyli zdefiniowanie go w taki sposób,

${ }^{23}$ G. Rodriguez-Pereyra, Nominalism in metaphysics, [w:] E. N. Zalta (ed.), The Stanford Encyclopedia of Philosophy, Fall 2011 Edition; http://plato.stanford.edu/archives/fall2011/entries/ nominalism-metaphysics (dostęp: 23.04.2014).

${ }^{24}$ Chociaż możliwe, np. D. Armstrong (1986) wykazał, że można być jednocześnie naturalistą i realistą w sporze o uniwersalia. Wątpliwe jest jednak, by Armstrong był realistą względem prawa.

${ }^{25}$ Redukcjonistyczny naturalizm w stosunku do prawa sprzyjałby nie tyle integracji, ile raczej zastępowaniu nauk prawnych naukami przyrodniczymi.

${ }^{26}$ Operacjonalizacja jako doktryna filozoficzna (szczególnie jako pewna teoria znaczenia) została poddana surowej krytyce. Wciąż jednak funkcjonuje w metodologii badań naukowych. 
aby możliwy stał się pomiar tego, do czego owo pojęcie się odnosi. Operacjonalizacja służy zwiększeniu „zawartości empirycznej” danego pojęcia. Zawartość empiryczna z kolei, według Imre Lakatosa, to zbiór empirycznie testowalnych predykcji ${ }^{27}$.

Chyba najbardziej radykalną formą m-naturalizmu jest naturalizm eliminacyjny (replacement naturalism), związany z programem znaturalizowanej epistemologii w duchu Quine’a. W swojej wyjściowej formie głosił on, że skoro przedsięwzięcia klasycznych epistemologów zawsze odbijają się od argumentów sceptyków (poznanie rzeczywistości nigdy nie może być pewne), to należy zarzucić taki program epistemologii i skupić się na badaniu tego, co jest nam bezpośrednio i empirycznie dostępne. Zdaniem Quine'a możliwe jest badanie tego, w jaki sposób formułujemy nasze sądy. Mówiąc wprost, według Quine’a epistemologię powinna zastąpić psychologia eksperymentalna ${ }^{28}$.

Naturalizm eliminacyjny przeniesiony na grunt teorii prawa wiąże się $\mathrm{z}$ dwiema tezami:

1) analiza pojęciowa jako metoda prawoznawstwa powinna zostać zastąpiona przez metody nauk społecznych ${ }^{29}$;

2) obecne w prawie teorie o charakterze normatywnym powinny zostać zastapione teoriami o charakterze empirycznym.

Powyższe tezy stawiają pod znakiem zapytania program integracji zewnętrznej nauk prawnych - postulują one eliminację metod charakterystycznych dla prawoznawstwa (jak np. analiza pojęciowa). Kwestionują też tezę o metodologicznej wielopłaszczyznowości prawoznawstwa, ograniczając dopuszczalne metody i narzędzia badawcze wyłącznie do tych akceptowalnych przez nauki społeczne.

${ }^{27}$ Podobnie Karl Popper, dla którego zawartość empiryczna twierdzenia $p$ to klasa jego potencjalnych falsyfikatorów: „I define the empirical content of a statement $p$ as the class of its potential falsifiers" - zob. J. Bogen, Theory and observation in science, [w:] E. N. Zalta (ed.), The Stanford Encyclopedia of Philosophy, Spring 2010 Edition; http://plato.stanford.edu/archives/ spr2010/entries/science-theory-observation (dostęp: 23.04.2014) oraz H. Chang, Operationalism, [w:] E. N. Zalta (ed.), The Stanford Encyclopedia of Philosophy, Fall 2009 Edition; http://plato. stanford.edu/archives/fall2009/entries/operationalism (dostęp: 23.04.2014).

${ }^{28}$ W. V. O. Quine, Ontological Relativity and Other Essays, New York 1969.

${ }^{29}$ Standardowy argument za tą tezą wygląda następująco: analiza pojęciowa wymaga jako punktu wyjścia określonych intuicji związanych z danym pojęciem. Nie budzi to wątpliwości, gdy te intuicje podzielane są powszechnie. W sytuacji, gdy tak nie jest - brak kryterium rozstrzygania sporów. Takie kryterium występuje w naukach empirycznych. B. Leiter (zob. Naturalism in Legal Philosophy, [w:] The Stanford Encyclopedia of Philosophy, Fall 2008 Edition; http://plato.stanford.edu/archives/fall2008/entries/lawphil-naturalism [dostęp: 23.04.2014]) polemizuje podobnie z J. Colemanem (zob. The Practice of Principle, Oxford 2001), który zwraca uwagę, iż metody empiryczne raczej nie zakończą sporów odnośnie do natury prawa. Leiter wskazuje, że zapewne jest to prawdą, ale o ile epistemicznie dane $\mathrm{z}$ analizy pojęciowej czy intuicji nie są w żaden sposób uprzywilejowane, to dane empiryczne już tak. I w tym leży ich wartość. 


\section{Przykłady ujęć naturalizmu w teorii prawa}

Warto podkreślić, że metodologiczny naturalizm eliminacyjny nie jest stanowiskiem tylko potencjalnie dostępnym w obrębie teorii prawa. Historycznie głoszony był m.in. przez amerykańskich realistów; współcześnie zaś pewna jego reinterpretacja broniona jest przez Briana Leitera ${ }^{30}$.

Amerykańscy realiści kwestionowali sensowność badania związku pomiędzy racjami prawnymi a decyzjami sędziów. Teorie normatywne wskazują sędziemu, jak powinien się zachować w określonej sytuacji prawnej. Stanowisko realistów było antyfundacjonalistyczne, tj. kwestionowali oni pogląd, jakoby racje prawne stanowiły uzasadnienie dla podejmowanych przez sędziów decyzji - w tym znaczeniu, w jakim określone dane zmysłowe nie uzasadniają teorii naukowej. Inaczej mówiąc, uzasadnienie tego, jak być powinno (w tym wypadku tego, jaką decyzję powinien podjąć sędzia), nie jest możliwe, a na pewno nie za pośrednictwem racji prawnych ${ }^{31}$.

W rezultacie realiści proponowali eliminację teorii normatywnych i zastapienie ich opisowymi - zamiast zadawać pytanie, jakie są racje, dla których sędziowie podejmują określone decyzje, woleli pytać o to, jaki układ pozaprawnych czynników wiąże się z określonym zachowaniem sędziego. W efekcie postulowali zastąpienie klasycznych metod prawoznawstwa m.in. psychologią behawioralną, ekonomią czy socjologią.

Problem takiego podejścia wiąże się z tym, że chociaż pozwala ono na wyjaśnienie przy pomocy racji pozaprawnych faktu, jakim jest podjęcie przez sędziego określonej decyzji (a być może nawet przewidywanie, jakie decyzje ów sędzia będzie podejmował w przyszłości), to okazuje się jednak mało użyteczne dla samego sędziego. Sędzia, podejmując decyzję, potrzebuje przecież konkretnych racji prawnych, na których może tę decyzję oprzeć. Radykalny metodologiczny naturalista eliminacyjny musiałby albo zaproponować naturalistyczną teorię uzasadnienia, albo byłby zmuszony uznać, że prawoznawstwo nie jest dziedziną naukową (a zajmowanie się nim można porównać z błądzeniem w ciemnościach).

Na gruncie teorii prawa formułowano również teorie bliskie naturalizmowi ontologicznemu, w szczególności w kręgach realistów skandynawskich. Postulowali oni, iż twierdzenia normatywne można zredukować do pewnych twierdzeń psychologicznych (behawioralnych). Głosili, że prawo wtedy należy uznać za obowiązujące, gdy można przewidzieć, iż sędziowie będą zgodnie z nim postępować i będą czuć się zobowiązani do tego postępowania. H. L. A. Hart w swojej słynnej krytyce tych poglądów wskazał, że z perspektywy sędziego, który podejmuje decyzję, taka definicja obowiązującego prawa nie ma żadnego sensu ${ }^{32}$. Sędzia musi uznać daną

${ }^{30}$ B. Leiter, op. cit.

${ }^{31}$ Ibidem.

${ }^{32}$ H. L. A. Hart, Scandinavian Realism, Cambridge 1959, [przedruk w:] idem, Essays in Jurisprudence and Philosophy, Oxford 1983. 
normę za obowiązująca, zanim postąpi zgodnie z jej wskazaniami. Jest to krytyka analogiczna do zasygnalizowanej krytyki realizmu amerykańskiego, który jednak nie postulował tak daleko idących zobowiązań ontologicznych. Co ciekawe, krytyka Harta w niewielkim stopniu dotyczy kwestii stricte ontologicznych; skierowana jest raczej na nieadekwatność sugerowanych przez realistów (głównie skandynawskich, w mniejszym stopniu amerykańskich) metod poznania na gruncie prawoznawstwa. Radykalny naturalista mógłby zignorować krytykę Harta, utrzymując, że obowiązywanie, o którym on mówi, albo nie ma tak naprawdę miejsca ${ }^{33}$, albo wymyka się poznaniu empirycznemu i jako takie go nie interesuje.

Inną odpowiedzią na krytykę Harta mógłby być naturalizm normatywny Goldmana $^{34}$. Postuluje on, iż teorie normatywne muszą być spójne z teoriami naukowymi. Oznacza to, że normy, którymi się kierujemy (a zatem można przypuszczać, że również normy prawne, którymi kieruje się sędzia), sprzyjają osiąganiu pewnych celów. Cele te mogą być poznane empirycznie na gruncie nauki ${ }^{35}$. W efekcie można postulować, iż sędzia powinien podejmować takie decyzje, które najefektywniej służą osiąganiu owych celów.

\section{Konsekwencje naturalizmu}

Podsumowując dotychczasowe rozważania, trzeba ponownie podkreślić, że naturalizm jest stanowiskiem bardzo szerokim i nie należy go postrzegać przez pryzmat określonego, wąskiego jego ujęcia. To, co charakterystyczne dla naturalizmu jako takiego, to jego afirmacja empirii jako wyznacznika tego, co jest (s-naturalizm), albo tego, co może być poznane (m-naturalizm). Nie przesądza to jednak ani o statusie ontologicznym prawa, ani o wartości metod prawoznawstwa.

Należy przy tym odróżnić naturalizm jako stanowisko ontologiczno-metodologiczne na gruncie teorii prawa od „postawy naturalistycznej”, której występowanie stanowi co najwyżej pewną obserwację socjologiczną, do tego osadzoną w danym kontekście historycznym i społecznym. Skupianie się na tej drugiej może prowadzić do stawiania tak zaskakujących tez, jak ta, iż naturalizm sprzyja „postawie afilozoficznej”. Jest to teza nie tylko nieuzasadniona, lecz także paradoksalna, sugerująca, że zwolennik dominującego we współczesnej filozofii stanowiska metafizycznego reprezentuje postawę afilozoficzną - niepowoływania się na twierdzenia filozoficzne (sic!).

${ }^{33}$ Co można by rozumieć w ten sposób, że prawo nie ma mocy obowiązującej, a racje, które podaje sędzia dla uzasadnienia swoich decyzji są najwyżej wtórną racjonalizacją.

${ }^{34}$ A. I. Goldman, Epistemics: The regulative theory of cognition, „Journal of Philosophy” 1978, vol. 75 .

${ }^{35}$ Podobnej tezy zdaje się bronić W. Załuski w ewolucyjnej teorii prawa. Sugeruje on, że takie cele są poznawalne np. na gruncie teorii prawa, która może potem funkcjonować jako uzasadnienie dla norm bliższych naturze ludzkiej. 
Bardziej złożony jest problem związku przyjęcia naturalizmu na gruncie teorii prawa dla tez o wielopłaszczyznowości ontologicznej i metodologicznej oraz dla zagadnienia integracji zewnętrznej prawoznawstwa.

Trzeba ponownie podkreślić, że ze swej istoty naturalizm ogranicza zbiór uznawanych bytów (s-naturalizm) czy metod badawczych (m-naturalizm). W tym kontekście naturalizm zagraża tezie o wielopłaszczyznowości, zamiast jej bronić. Naturaliści redukcjoniści będą zwalczać tezę o ontologicznej złożoności prawa (a będąc dodatkowo nominalistami czy eliminatywistymi prawnymi, mogą w ogóle kwestionować istnienie bytu, jakim jest prawo). Z kolei naturaliści eliminacyjni będą postulować nie tyle rozszerzenie zbioru dostępnych prawnikom metod badawczych, ile ich ograniczenie do tych tylko, które bazują na empirii.

To, że akceptacja naturalizmu w pewien sposób „otwiera” nauki społeczne $\mathrm{i}$ humanistyczne na naukę w znaczeniu science oraz zwiększa ich zainteresowanie badaniami empirycznymi, stanowi pewną socjologiczną obserwację. Należy mieć świadomość, iż w najbardziej radykalnym wydaniu naturalizm postuluje zastąpienie nauk społecznych i humanistycznych naukami przyrodniczymi lub nawet kwestionuje istnienie przedmiotu ich zainteresowań.

Teza głosząca, że naturalizm w teorii prawa sprzyja programom integracji zewnętrznej nauk prawnych, podczas gdy antynaturalizmowi bliżej do programów autonomicznych - również stanowi pewną mniej lub bardziej uzasadnioną obserwację socjologiczną. Już realiści amerykańscy postulowali rezygnację z metod prawoznawstwa na rzecz metodologii nauk społecznych. Integracji zewnętrznej nauk prawnych nie sprzyjają z pewnością te postacie naturalizmu, które kwestionują w ogóle sensowność uprawiania prawoznawstwa i zajmowania się takimi zagadnieniami, jak obowiązywanie prawa czy normatywność.

Oczywiście, w obrębie naturalizmu występują kierunki, które mogą sprzyjać procesom integracji zewnętrznej - w szczególności te postulujące realizm ontologiczny w stosunku do prawa oraz nastawione antyredukcjonistycznie. Bez wątpienia jednak również antynaturalizm otwiera prawoznawstwo na metody inne niż analiza pojęciowa. To właśnie antynaturalizmowi bliskie są postulaty ontologicznej złożoności rzeczywistości oraz różnorodności skutecznych metod poznania (nie tylko empirycznych i nie tylko naukowych). 